\title{
Awareness and Attitude Toward Eye Donation among Medical Students in Qassim University - A Cross-sectional Study, 2019
}

\author{
Sultan Abdulaziz Alzuhairy ${ }^{1 *}$, Abdulrahman Sulaiman Alfarraj ${ }^{2}$, Meshari Mubarak Alharbi $^{2}$, Raghad Juidan Alhomidani ${ }^{3}$ \\ ${ }^{1}$ Department of Ophthalmology, Qassim University, Saudi Arabia, Qassim - Buraydah, Saudi Arabia; ${ }^{2}$ Intern, College of Medicine, \\ Qassim University, Qassim, Saudi Arabia; ${ }^{3}$ Medical Student, College of Medicine, Qassim University, Qassim, Saudi Arabia
}

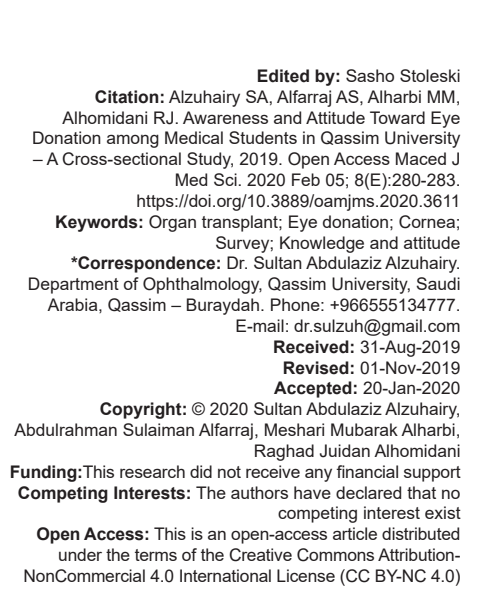

Introduction

Corneal pathologies although declined, still contribute substantially to the global burden of visual disability [1]. Most of them could be treated by corneal transplant and vision could be restored that remains stable even after 5 years [2]. Although it is leading organ to be transplanted with highest success rate, the demand is far more than supply [3]. In Saudi Arabia, many keratoplasty surgeries are performed, but only two of them were using local donated eyes [4], [5]. To increase corneal harvesting locally, all efforts should be done. Medical students are the future first-line health staff that interacts with terminal patients and their relatives. If they have adequate knowledge and positive attitude toward eye donation, they will be able to counsel and convince for eye donation.

Assessmentofawarenessandattituderegarding eye donation among health staff has been carried out in Indian and African subcontinent [6], [7], [8]. However, to the best of our knowledge, only one survey targeting medical students has been conducted in Riyadh, Saudi Arabia, recently [9].

We conducted a survey targeting medical students of Qassim University of Saudi Arabia and present the level of awareness and attitude for eye donation and their determinants.

\section{Methods}

The ethical committee of Qassim University approved of this cross-sectional survey. All medical students of this university were study population. Those agreeing to participate were surveyed. Their identity was delinked from the analyzed data.

Approximately, there are six hundred medical students (as a total population) in the college of medicine at Qassim university. The acceptable level of knowledge among medical students will be in 74\% [6]. To achieve $95 \%$ confidence interval and acceptable error margin of $5 \%$ with clustering effect of 2 , we need to survey at least 397 medical students.

The survey comprised three sections; demographic data, 10 questions related to knowledge about eye donations, one question about student's willingness to donate his/her own eyes, and one question regarding barrier for not donating eyes. The correct 
answer for each question was based on the consensus response of three expert cornea specialists. This was compared to the response of medical student. If there was agreement in the reply +1 score was awarded. If student had wrong answer or did not know the answer, 0 score was given. The sum of all 10 questions of knowledge was further graded as "5 and more" (good knowledge) and "<5 score" (poor knowledge).

The SurveyMonkey ${ }^{\circledR}$ software was used to collect data [10]. The data were then transferred into a spreadsheet of Statistical Package for the Social Sciences (SPSS 25) (IBM, Chicago, USA). The qualitative data were presented as frequencies and percentage proportions. The quantitative data were first plotted to study its distribution. In case of normal distribution, their mean and standard deviations were estimated. The knowledge score grade was associated to other variable to calculate odds ratio, its $95 \%$ confidence interval, and two-sided $p$ values. $p<0.05$ was considered as statistically significant.

\section{Results}

Of the 600 medical students, 386 (64\%) participated in the present survey. The demographic profile of the participants is given in Table 1.

Table 1: Profile of medical students (survey participants)

\begin{tabular}{|c|c|c|c|}
\hline \multirow[t]{3}{*}{ Age } & \multirow{3}{*}{$\begin{array}{l}\text { Mean } \\
\text { SDV }\end{array}$} & \multicolumn{2}{|l|}{22.0} \\
\hline & & \multicolumn{2}{|l|}{1.9} \\
\hline & & Number & Percentage \\
\hline \multirow[t]{2}{*}{ Gender } & Male & 260 & 67.4 \\
\hline & Female & 126 & 33.6 \\
\hline \multirow[t]{2}{*}{ Marital status } & Married & 7 & 1.8 \\
\hline & Unmarried & 379 & 98.2 \\
\hline \multirow[t]{5}{*}{ Education level } & $1^{\text {st }}$ year & 84 & 21.8 \\
\hline & $2^{\text {nd }}$ year & 61 & 15.8 \\
\hline & $3^{\text {rd }}$ year & 90 & 23.3 \\
\hline & $4^{\text {th }}$ year & 99 & 25.6 \\
\hline & $5^{\text {th }}$ year & 52 & 13.5 \\
\hline \multirow[t]{2}{*}{ Had ophthalmology course } & Yes & 135 & 35 \\
\hline & No & 251 & 65 \\
\hline
\end{tabular}

The rate of "Good grade" of knowledge regarding eye donation was $19.2 \%(95 \% \mathrm{Cl} 15.2 ; 23.1)$ among medical students.

The response to each of 10 knowledge related questions is given in Table 2 .

Table 2: Response of the study participants to the questions about eye donation

\begin{tabular}{|c|c|c|c|c|}
\hline \multirow[t]{2}{*}{$(n=386)$} & \multicolumn{2}{|c|}{ Correct answer } & \multicolumn{2}{|c|}{ Wrong answer } \\
\hline & & $\%$ & & $\%$ \\
\hline $\begin{array}{l}\text { Which part of the donated eye is transplanted to the } \\
\text { needy eye patient? }\end{array}$ & 171 & 44.3 & 251 & 65.0 \\
\hline In which eye diseases donated eye is useful? & 126 & 32.6 & 260 & 67.4 \\
\hline When should eye should be taken from donor? & 169 & 43.8 & 217 & 56.2 \\
\hline How much time it takes to collect donated eye? & 43 & 11.1 & 243 & 63.0 \\
\hline Can you tell eye patient who donated eyes to him/her? & 35 & 9.1 & 351 & 90.9 \\
\hline $\begin{array}{l}\text { How many persons can gain vision using a donor's } \\
\text { eyes? }\end{array}$ & 80 & 20.7 & 306 & 79.3 \\
\hline Who can decide if your eyes can be donated? & 386 & 100.0 & 0 & 0.0 \\
\hline $\begin{array}{l}\text { If you have undergone eye surgery, can you donate } \\
\text { your eyes? }\end{array}$ & 43 & 11.1 & 343 & 88.9 \\
\hline $\begin{array}{l}\text { How long a donated eye can be preserved for } \\
\text { transplantation? }\end{array}$ & 19 & 4.9 & 367 & 95.1 \\
\hline Does Islam religion permit you to donate your eyes? & 172 & 44.6 & 214 & 55.4 \\
\hline
\end{tabular}

All medical students knew who can give consent for eye donation. Few participants knew about duration of harvested tissue can be preserved (5\%) and recipient can be informed about donor's identity (9\%).

Attitude to donate eye was positive in 102 (26.4\% [95\% Cl 22.0; 30.8]) medical students. It was negative in $105(27.2 \%$ [95\% Cl 22.8; 31.6]) medical students. Of the surveyed medical students, 179 $(46.5 \%)$ were undecided about their own eye donation.

Among those who expressed willingness to donate their eyes, the response to possible barrier for not donating is given in Table 3.

Table 3: Reasons for not willing to donate eyes

\begin{tabular}{lll}
\hline Reasons for not willing to donate eyes & Number & Percentage \\
\hline Religion does not permit & 22 & 5.7 \\
Objection from family & 52 & 13.5 \\
Worried about body status after eye removal & 67 & 17.1 \\
Medical history makes one ineligible for eye donation & 39 & 10.1 \\
Need more information to decide & 146 & 37.8 \\
Other & 42 & 10.9 \\
\hline
\end{tabular}

Lack of adequate knowledge was the main reason for undermined status of medical students for eye donation.

Among 74 medical students with good knowledge about eye donation, willingness to donate eyes was in 31 (41.9\%) students. Among 234 participants with poor level of knowledge, willingness to donate eye was in 71 (30.3\%) of medical students. The level of knowledge about eye donation was positively and significantly associated to attitude to donate eyes (OR $=2.44$ [95\% Cl 1.4; 4.2], $p=0.001)$.

Among 160 male students, level of knowledge about eye donation was good in 50 (19.2\%) students while it was good in $24(19 \%)$ of 126 female students. The association of knowledge regarding eye donation to gender of medical students was not statistically significant $(p=0.97)$.

The variation of good level of knowledge about eye donation by the academic year of the medical students was not statistically significant $(\chi 2=0.3, d f=4, p=0.6)$.

The level of knowledge about eye donation among medical students did not differ by their attendance to ophthalmology course in the university (OR $=0.94$ [95\% Cl 0.5; 1.6], $p=0.8$ ).

\section{Discussion}

Medical students of Qassim University had low rate of knowledge about eye donation and use of donated eye. Their willingness to donate their own eyes was also low and was positively associated to the lack of awareness about eye donation. The level of knowledge did not vary by gender and seniority in medical college.

This is perhaps the first study of future doctors who would be front line battalion interacting with 
patients and their relatives and potent motivators for eye donation. In view of low knowledge and attitude, there is urgent need to intervene in Qassim region of Saudi Arabia.

The low level of awareness noted in the present study matched with the findings of a study targeting Nigerian medical students [11]. This is in contrast to high level of awareness about eye donation and corneal transplant displayed by Malaysian students and medical students of Delhi [8], [12]. Involving medical students in World Sight Day activities, health promotion about eye donation, inclusion of this issue in curriculum of medical students, and use of social media to increase awareness could be some strategies to improve awareness regarding eye donation, corneal transplant [13], [14].

In our study, there was variation in knowledge about different component of eye donation and corneal tissue utilization for restoring eyesight. Medical students were fully aware about who can give consent for eye donation and when but knowledge about when to remove donor tissue and need to maintain anonymity of the donor was very poor. The variation in awareness about different aspects of eye donation and transplant was also noted among medical students in other studies [7], [15].

Nearly one-third of participation was by female students in the present study. With such participants profile, it is surprising not to find gender difference in knowledge level. Health promotion for eye donation and corneal transplant, therefore, need not be separate and gender specific in the study area.

The awareness about eye donation and corneal transplant was not different by student's number of years in medical college. With as low as $13 \%$ of awareness, effect of level in medical college is least expected. The package for health promotion, therefore, could be common for all.

In the study area, there are no eye bank and few cornea surgeons mainly doing corneal graft using imported cornea. Thus, exposure of tissue harvesting and utilization to the medical students is minimum. This explains low awareness and challenges that lay ahead for improving the knowledge and willingness to donate eye among participants.

The barriers identified for eye donation among these educated population are worth noting. Religious taboo for eye donation is nonexistent. However, this information is still not reached to $5 \%$ of medical students. A common practice of providing artificial eye shell and maintain esthetic look of cadaver after eye removal should be conveyed to medical students.

Improving the knowledge will improve the attitude of medical students. Then, they will be good promoters of eye donation and increase generation of local donor material. It will be too early to study the impact of any intervention done to address the identified barriers.

\section{Conclusions}

The overall awareness of medical students regarding eye donation was low. We can improve students' knowledge and attitude toward eye donation through health promotion, inclusion of eye donation in undergraduate curriculum, and good ophthalmic training. Further multicenter studies in addition to population-based surverys are needed.

\section{Acknowledgment}

We would acknowledge Abdullah Saleh Alrakebeh, Ahmed Abdulaziz AlOrini, Ghayda Saleh Alwahbi, Hareth Nasir Alhujaili, and Nasser Ahmed Alnasser for their effort in data collection.

\section{References}

1. Flaxman SR, Bourne RR, Resnikoff S, Ackland P, Braithwaite T, Cicinelli MV, et al. Global causes of blindness and distance vision impairment 1990-2020: A systematic review and metaanalysis. Lancet Glob Health. 2017;5(12):e1221-34. https://doi. org/10.1016/s2214-109x(13)70113-x

2. Chow SP, Hopkinson CL, Tole DM, Jones MN, Cook SD, Armitage WJ. Stability of visual outcome between 2 and 5 years following corneal transplantation in the UK. $\mathrm{Br} \mathrm{J}$ Ophthalmol. 2018;102(1):37-41. https://doi.org/10.1136/ bjophthalmol-2016-310129

PMid:28600303

3. Wong KH, Kam KW, Chen LJ, Young AL. Corneal blindness and current major treatment concern-graft scarcity. Int J Ophthalmol. 2017;10(7):1154

PMid:28730122

4. Gain P, Jullienne R, He Z, Aldossary M, Acquart S, Cognasse F, et al. Global survey of corneal transplantation and eye banking. JAMA Ophthalmol. 2016;134(2):167-73. https://doi.org/10.1001/ jamaophthalmol.2015.4776

5. Saudi Center for Organ Transplantation. Statistical Summary Corneal Recovery. Available from: http://www.scot.gov.sa/ images/Report_En_F_Statistical\%20Summary.pdf. [Last accessed on 2019 Jul 03].

6. Lal B, Usgaonkar U, Narvekar H, Venugopal D. Awareness and knowledge on eye donation among allied health sciences, medical, and nursing students in Goa. J Curr Ophthalmol. 2018;30(3):255-62. https://doi.org/10.1016/j.joco.2018.02.002

7. Eze BI, Okoye O, Eze JN. Knowledge and attitudes regarding eye donation and corneal transplant: Medical versus nonmedical university students in a developing country in Africa. Exp Clin Transplant. 2014;12(5):454-61.

PMid:25299373

8. Singh MM, Rahi M, Pagare D, Ingle GK. Medical students perception on eye donation in Delhi. Indian J Ophthalmol. 2007;55(1):49-53. https://doi.org/10.4103/0301-4738.29495 PMid:17189887 
9. Alanazi LF, Aldossari SH, Gogandy MA, Althubaiti GA, Alanazi BF, Alfawaz AM. Attitude, beliefs and awareness towards corneal donation in Saudi Arabia. Saudi J Ophthalmol. 2019;33(2):121-9. https://doi.org/10.1016/j. sjopt.2019.02.003

10. Halim MA, Foozy CF, Rahmi I, Mustapha A. A review of live survey application: Survey monkey and survey Gizmo. JOIV Int J Inform Vis. 2018;2(4-2):309-12. https://doi.org/10.30630/ joiv.2.4-2.170

11. Okoye Ol, Maduka-Okafor FC, Eze BI. What does the medical student know about eye donation/corneal transplant? The university of Nigeria scenario. West Indian Med J. 2010;59(1):41-4.

PMid:20931912

12. Bharti MK, Reddy SC, Tajunisah I, Ali NA. Awareness and knowledge on eye donation among university students. Med $\mathrm{J}$ Malaysia. 2009;64(1):41-5.
PMid: 19852320

13. Hubley J, Gilbert C. Eye health promotion and the prevention of blindness in developing countries: Critical issues. $\mathrm{Br} J$ Ophthalmol. 2006;90(3):279-84. https://doi.org/10.1136/ bjo.2005.078451

PMid: 16488944

14. Hudnut-Beumler J, Po'e E, Barkin S. The use of social media for health promotion in hispanic populations: A scoping systematic review. JMIR Public Health Surveill. 2016;2(2):e32. https://doi. org/10.2196/publichealth.5579

PMid:27400979

15. Al-Labadi L, Gammoh Y, Shehada R, Shahin R, Jbarah W, Amro $\mathrm{M}$, et al. University students' knowledge of corneal donation and willingness to donate corneas in the occupied Palestinian territory: A cross-sectional study. Lancet. 2018;391 Suppl 2:S22. https://doi.org/10.1016/s0140-6736(18)30388-x PMid:29553420 